\title{
Climate policy, regulation and governance: introduction
}

\section{Simon Goldhill and Georgie Fitzgibbon}

Abstract: Regulatory systems and innovative policy solutions are addressing the current and future effects of climate change. The articles presented here range from broad views on climate change governance in agroforestry systems and insights from climate-funded food system projects, to the nationally specific, exploring regulatory contexts in the UK, China, and Mexico. They consider state, private, and civil society actors. Together, they demonstrate the importance of innovative policy solutions to climate regulatory and governance problems.

Keywords: Policy, regulation, governance, agroforestry, food systems, underground space, China, Mexico, civil society.

Notes on the authors:

Simon Goldhill is Professor of Greek at the University of Cambridge, and a Fellow of King's College, Cambridge. He was elected a Fellow of the British Academy in 2016, and currently serves as Foreign Secretary \& Vice-President of the British Academy.

Dr Georgie Fitzgibbon is Senior International Policy Adviser at the British Academy.

(C) The author(s) 2021. This is an open access article licensed under a Creative Commons Attribution-NonCommercial-NoDerivs 4.0 Unported License 
Regulatory systems and innovative policy solutions are addressing the current and future effects of climate change. A 2019 policy brief produced by the Grantham Research Institute on Climate Change and the Environment and Centre for Climate Change Economics and Policy states that a significant majority of countries have enacted laws and policies to address climate change adaptation. These often identify floods and droughts as major hazards, while impacts such as ocean acidification remain under-addressed. Framework laws and policies often include adaptation plans, information, regulation, and early warning systems, though there is a lack of adaptation investment and economic incentives to encourage adaptation. ${ }^{1}$

The articles presented here range from broad views on climate change governance in agroforestry systems and insights from climate-funded food system projects, to the nationally specific, exploring regulatory contexts in the UK, China, and Mexico. They consider state, private, and civil society actors. Together, they demonstrate the importance of innovative policy solutions to climate regulatory and governance problems.

In the first article, Pamela Katic (2021) presents a systematic review of climate change governance in agroforestry systems. Agroforestry has the potential fundamentally to transform socio-ecological systems in order to address the root causes of climate vulnerability. Although there is increasing interest in agroforestry as a transformative adaptation strategy, its implementation is often discouraged by the requirement to involve multiple stakeholders, sectors, and governance agents with potentially different interests. The author draws on a systematic review of sixty-four peer-reviewed papers on climate change governance in agroforestry systems to (1) outline the current state of the literature, (2) characterise how governance is conceptualised, (3) investigate governance challenges, and (4) provide insights into effective governance. The review finds that most relevant papers have been published in the past three years, and most of these papers are found in interdisciplinary journals. The main governance challenges include coordinating polycentricity, overcoming power imbalances and sharing, translating, and integrating different types of knowledge. However, few empirical studies of agroforestry governance have been completed. A richer conceptual framework of governance is required to improve our ability to navigate the role of sustainable land management practices such as agroforestry in successful climate change adaptation and mitigation.

Next Abrar Chaudhury and Saher Hasnain (2021) explore food projects funded by the Green Climate Fund (GCF). Climate change poses unprecedented and complex challenges to global food systems. Critical vulnerabilities, continuing inequalities, and unsustainability have demonstrated that food systems need significant intervention in order to deliver safe, just, and healthy food for all, against the backdrop of a changing climate. Innovative interventions and effective financing are needed across

${ }^{1}$ Nachmany et al. (2019). 
the food system to achieve these grand ambitions. While there is recognition of a systems approach in the face of complex issues such as climate change, interventions and financing mechanisms have historically focused narrowly on production or specific sectors within food and related systems. Given the diverse array of stresses and shocks, this approach will not achieve the desired paradigm shifts necessary to secure global food systems and meet the Paris Agreement climate targets. Through a comprehensive review of GCF-funded projects, this paper shows that paradigm shifting interventions can benefit from a food systems perspective by moving beyond specific sectors and activities and delivering outcomes across the socio-economic and environmental spheres. Climate change and food system challenges are complex and necessitate system approaches, and financing instruments need to be designed and structured with systemic complexity in mind.

In the first of a series of nationally focused contributions, Kevin Grecksch (2021) introduces the current situation of underground space governance and regulation in the UK. Underground space has been used by humans for thousands of years: for example, to extract mineral resources or water. Against the background of increasing populations, urbanisation, and energy demand, underground space has come back into focus, promising to ease pressure above the surface. However, geological underground models deliver no more than frameworks for possible uses; and we do not know enough about the interrelations between geological characteristics and the impact of potential human requirements of underground space. Moreover, governing underground space can be complicated as it involves conflicting objectives and regulatory frameworks. One key objective, therefore, must be to conceptualise and implement new approaches to underground governance, taking into account its diverse uses and various stakeholders' claims. Grecksch discusses different themes, such as property rights, regulation, planning, groundwater, fracking, and the future of underground space use exemplified by the storage of nuclear waste.

The penultimate article aims to survey and explain China's stance toward climate change and its investment in renewable energy in the past three decades from 1990 to 2020, encompassing Xi Jinping's tenure as leader and the impact of the COVID-19 pandemic. Hongyi Lai (2021) argues that, as for over a decade China has been the predominant carbon emitter in the global economy, it is imperative for us to understand the factors behind its climate change policy in the past decades. Lai argues that (neo-)realism/nationalism and liberalism, two main theories in the field of international relations, offer only partial explanations of China's climate policy. Instead, Lai highlights the importance of understanding China's domestic political economy, leadership considerations and the desire for economic growth, to understand the climate stances of nation-states. Policy suggestions for external parties to interact with China on climate change are proposed. There the importance of involving China in 
global action against climate change, as well as the utility of the economy and trade leverage, soft power standing, and the prevention of extreme weather are discussed.

Finally, Susan Baker, Bárbara Ayala-Orozco, and Eduardo García-Frapolli (2021) examine the role of civil society organisations (CSOs), including non-governmental environmental organisations, in climate governance. The authors utilise a case study approach with regard to the coastal zone of Quintana Roo, Mexico. Focus groups with key stakeholders and in-depth face-to-face and online interviews were employed to examine key-actor perceptions of climate change risk and their involvement in climate governance, across different scales. Participation by CSOs is shaped by a variety of factors, including constitutional arrangements, regulatory regimes, administrative traditions and structures, and a wider set of beliefs about moral responsibility and the exercise of civic duty. CSO participation across multilevel governance scales provides an array of inputs to help address climate vulnerabilities in the coastal zone of Quintana Roo. Especially under conditions of weak administrative capacity and corrupt government, certain enabling institutional conditions are needed. This creates complex contexts in which CSOs emerge, networks develop, alliances are formed, and barriers to effective participation endure.

This issue forms part of the British Academy's COP26 series, which aims to raise awareness of the importance of the humanities and the social sciences in understanding the complex human and social dimensions to environmental challenges and their solutions. The authors are drawn from a range of British Academy programmes, including the Postdoctoral Fellowships, the Sustainable Development Programme, which funds researchers working on the UN's Sustainable Development Goals, BA/Leverhulme Small Research Grants, which support primary research across the humanities and social sciences, and Knowledge Frontiers, which aims to enable different communities of knowledge and practice to illustrate the unique added value of international and interdisciplinary collaboration.

\section{References}

Baker, S., Ayala-Orozco, B. \& García-Frapolli, E. (2021), 'The Role of Civil Society Organisations in Climate Change Governance: Lessons from Quintana Roo, Mexico', Journal of the British Academy, 9(s10): 99-126. https://doi.org/10.5871/jba/009s10.099

Chaudhury, A. \& Hasnain, S. (2021), 'Financing Food System Transformation:Insights from Global Climate Projects', Journal of the British Academy, 9(s10): 21-42. https://doi.org/10.5871/jba/009s10.021

Grecksch, K. (2021), 'Out of Sight - Out of Regulation? Underground Space Governance in the UK', Journal of the British Academy, 9(s10): 43-68. https://doi.org/10.5871/jba/009s10.043 
Katic, P. (2021), 'Climate Change Governance in Agroforestry Systems: A Systematic Review', Journal of the British Academy, 9(s10): 7-20. https://doi.org/10.5871/jba/009s10.007

Lai, H. (2021), 'The Evolution of China's Climate Change Policy: International and Domestic Political Economy and a Strategy for Working with China', Journal of the British Academy, 9(s10): 69-98. https://doi.org/10.5871/jba/009s10.069

Nachmany, M., Byrnes, R. \& Surminski, S. (2019), 'Policy Brief. National Laws and Policies on Climate Change Adaptation: A Global Review' (Grantham Research Institute on Climate Change and the Environment/Centre for Climate Change Economics and Policy). https://www.lse.ac.uk/ granthaminstitute/wp-content/uploads/2019/12/National-laws-and-policies-on-climate-changeadaptation_A-global-review.pdf

To cite the article: Simon Goldhill and Georgie Fitzgibbon (2021), 'Climate policy, regulation and governance: introduction', Journal of the British Academy, 9(s10): 1-5. DOI https://doi.org/10.5871/jba/009s10.001

Journal of the British Academy (ISSN 2052-7217) is published by The British Academy, 10-11 Carlton House Terrace, London, SW1Y 5AH www.thebritishacademy.ac.uk 
